\title{
SERÁ O DIREITO AO MEIO AMBIENTE SADIO E EQUILIBRADO UM DIREITO FUNDAMENTAL? EM BUSCA DA NOTA DE FUNDAMENTALIDADE DO DIREITO AO MEIO AMBIENTE ECOLOGICAMENTE EQUILIBRADO
}

\author{
Marco Túlio Reis Magalhães*
}

\section{Introdução}

O presente artigo busca analisar alguns aspectos relevantes do direito ao meio ambiente ecologicamente equilibrado - enquanto norma constitucional veiculada com base no disposto no artigo 225 da Constituição Federal brasileira ${ }^{1}$, por meio de alguns apontamentos que se podem formular a respeito, em face de algumas contribuições da moderna dogmática de direitos fundamentais. Nesse sentido, toma-se como eixo norteador de discussão o

\footnotetext{
* Mestrando em Direito pela Universidade de Brasília - UnB, área de Concentração: Direito, Estado e Constituição. E-mail: marucosam@yahoo.com.br .

1 “Art. 225. Todos têm direito ao meio ambiente ecologicamente equilibrado, bem de uso comum do povo e essencial à sadia qualidade de vida, impondo-se ao Poder Público e à coletividade o dever de defendê-lo e preservá-lo para as presentes e futuras gerações.

$\S 1^{\circ}$ - Para assegurar a efetividade desse direito, incumbe ao Poder Público:

I - preservar e restaurar os processos ecológicos essenciais e prover o manejo ecológico das espécies e ecossistemas; (Regulamento)

II - preservar a diversidade e a integridade do patrimônio genético do País e fiscalizar as entidades dedicadas à pesquisa e manipulação de material genético; (Regulamento)

III - definir, em todas as unidades da Federação, espaços territoriais e seus componentes a serem especialmente protegidos, sendo a alteração e a supressão permitidas somente através de lei, vedada qualquer utilização que comprometa a integridade dos atributos que justifiquem sua proteção; (Regulamento)

IV - exigir, na forma da lei, para instalação de obra ou atividade potencialmente causadora de significativa degradação do meio ambiente, estudo prévio de impacto ambiental, a que se dará publicidade; (Regulamento)

V - controlar a produção, a comercialização e o emprego de técnicas, métodos e substâncias que comportem risco para a vida, a qualidade de vida e o meio ambiente; (Regulamento)

VI - promover a educação ambiental em todos os níveis de ensino e a conscientização pública para a preservação do meio ambiente;

VII - proteger a fauna e a flora, vedadas, na forma da lei, as práticas que coloquem em risco sua função ecológica, provoquem a extinção de espécies ou submetam os animais à crueldade. [...]" BRASIL. Constituição (1998). Constituição da República Federativa do Brasil: Texto constitucional promulgado em 5 de outubro de 1988, com as alterações adotadas pelas Emendas Constitucionais $n^{\circ} 1 / 92$ a 46/2005 e pelas Emendas Constitucionais de Revisão n¹ a 6/94. Brasília: Senado Federal, Subsecretaria de Edições Técnicas, 2005. p. 58

PRISMAS: Dir., Pol.Pub. e Mundial., Brasília, v.3, n, 2, p. 288-311, jul/dez.2006 
enquadramento que se deu a este direito na ADI 3.540-MC/DF pelo Supremo Tribunal Federal - STF, com destaque ao voto do Ministro relator Celso de Mello².

De acordo com esse norte, pergunta-se pela fundamentalidade ${ }^{3}$ deste direito e pela delimitação do bem jurídico que ele busca proteger, com apoio, inicialmente, na doutrina ambiental, contrastada com duas perspectivas dogmáticas a respeito de direitos fundamentais. A par dessas considerações, busca-se, em retomada à decisão já referida, avaliar a necessidade de maior esclarecimento conceitual e metodológico da questão da proteção ambiental, não só diante, mas também dentro da moderna dogmática de direitos fundamentais e da sua repercussão nas decisões judiciais.

O que interessa ao artigo, portanto, é a fundamentação que se explicita por meio da discussão acerca dos seguintes pontos: caracterização do direito ao meio ambiente ecologicamente equilibrado como um direito (fundamental ou não) de terceira geração; tensão entre os valores ambientais, de um lado, e econômicos e/ou de livre iniciativa, de outro, enquanto bens constitucionalmente assegurados; possibilidade de tal direito vir a integrar uma colisão de direitos e o método que se propõe para tanto.

\footnotetext{
${ }^{2}$ Trata-se de medida cautelar em sede de ação direta de inconstitucionalidade (ADI 3.540-MC/DF) contra artigo de medida provisória, que alterou o Código Florestal, que dispôs que "a supressão de vegetação em área de preservação permanente somente poderá ser autorizada em caso de utilidade pública ou de interesse social, devidamente caracterizados e motivados em procedimento administrativo próprio, quando inexistir alternativa técnica e locacional ao empreendimento proposto.” Insurgiu o Procurador Geral da República contra tal prescrição legal, por entender configurada a "inconstitucionalidade formal dos referidos dispositivos por violação ao art. 225, $\S 1^{\circ}$, III, da Constituição Federal." BRASIL. Supremo Tribunal Federal. Medida Cautelar em Ação Direta de Inconstitucionalidade 3.540-1 - Distrito Federal (ADI 3.540 - MC/DF). Relator: Ministro Celso de Melo. Julgado em 01 de setembro de 2005. Diário de Justiça, Brasília, 03 fev. 2006. Disponível em: $<\mathrm{http}: / /$ www.stf.gov.br/ jurisprudencia/IT/frame.asp?PROCESSO=3540\&CLASSE=ADI\%2DMC\&cod_classe=555\&ORIGEM=IT\&R ECURSO=0\&TIP JULGAMENTO=M\&EMENTA=2219>. Acesso em: 24 ago. 2005.

3 "A categoria de $<$ fundamentabilidade $>$ aponta para a especial dignidade de proteção dos direitos num sentido formal e num sentido material. [...] A fundamentabilidade formal, geralmente associada à constitucionalização, assinala quatro dimensões relevantes: (1) as normas consagradoras de direitos fundamentais, enquanto normas fundamentais, são normas colocadas no grau superior da ordem jurídica; (2) como normas constitucionais encontram-se submetidas aos procedimentos agravados de revisão; (3) como normas incorporadoras de direitos fundamentais passam, muitas vezes, a constituir limites para a própria revisão; como normas dotadas de vinculatividade imediata dos poderes públicos constituem parâmetros materiais de escolhas, decisões, acções e controlo, dos órgãos legislativos, administrativos e jurisdicionais. [...] A idéia de fundamentabilidade material insinua que o conteúdo dos direitos fundamentais é decisivamente constitutivo das estruturas básicas do Estado e da sociedade. [...] Por outro lado, só a idéia de fundamentabilidade material pode fornecer suporte para: (1) abertura da constituição a outros direitos, também fundamentais, mas não constitucionalizados; (2) a aplicação a estes direitos só materialmente constitucionais de alguns aspectos do regime jurídico inerente à fundamentabilidade formal; (3) a abertura a novos direitos fundamentais. Daí falar-se, nos sentidos (1) e (3), em cláusula aberta ou em princípio da não tipicidade dos direitos fundamentais." CANOTILHO, José Joaquim Gomes. Direito constitucional e teoria da constituição. 4. ed. Coimbra: Almedina, 2001. p. 372373. 


\section{Sobre a nota de fundamentalidade do direito ao meio ambiente ecologicamente equilibrado}

\section{A defesa de um direito fundamental ao meio ambiente na decisão em análise}

A fundamentação do referido aresto, no voto do Ministro relator Celso de Mello, é clara no sentido de constatar que a preservação da integridade do meio ambiente é expressão constitucional de um direito fundamental que assiste à generalidade das pessoas e que os preceitos do artigo 225, CF/88, traduzem a consagração constitucional, em nosso sistema de direito positivo, de uma das mais expressivas prerrogativas asseguradas às formações sociais contemporâneas ${ }^{4}$. Reforça, pois, o caráter de fundamentalidade de tal direito a partir das características que lhe agregam a perspectiva histórica de gerações dos direitos fundamentais, a materializar poderes de titularidade coletiva atribuídos genericamente e de modo difuso a todos a consagrar o princípio da solidariedade. E tal premissa, a seguir analisada, fundamentase tanto no preceito da Declaração de Estocolmo sobre o Meio Ambiente (1972) ${ }^{5}$, como na posição doutrinária de diversos autores.

Análise da doutrina que sustenta os argumentos da decisão - essencialmente sob a ótica da doutrina do direito ambiental constitucional

A decisão do caso lastreia-se em uma gama de doutrinadores, mormente envolvidos com a temática ambiental, para ressaltar a fundamentalidade de tal direito, consagrando-o como um direito fundamental. Destaca-se como exemplo o entendimento de alguns deles. Edis Milaré considera o direito a um meio ambiente sadio como direito

\footnotetext{
${ }^{4}$ Em suas palavras: "Trata-se, consoante já o proclamou o Supremo Tribunal Federal, de um típico direito de terceira geração (ou de novíssima dimensão), que assiste, de modo subjetivamente indeterminado, a todo o gênero humano, circunstância essa que justifica a especial obrigação - que incumbe ao Estado e à própria coletividade - de defendê-lo e de preservá-lo em benefício das presentes e futuras gerações, evitando-se, desse modo, que irrompam, no seio da comunhão social, os graves conflitos intergeneracionais marcados pelo desrespeito ao dever de solidariedade na proteção da integridade desse bem essencial de uso comum de todos quantos compõem o grupo social." E consta o seguinte na ementa desse aresto: "A preservação da integridade do meio ambiente: expressão constitucional de um direito fundamental que assiste à generalidade das pessoas.” BRASIL. Supremo Tribunal Federal. Medida Cautelar em Ação Direta de Inconstitucionalidade 3.540-1 - Distrito Federal (ADI 3.540 - MC/DF). Relator: Ministro Celso de Melo. Julgado em 01 de setembro de 2005. Diário de Justiça, Brasília, 03 fev. 2006. Disponível em $<$ http://www.stf.gov.br/jurisprudencia/IT/frame.asp?PROCESSO=3540\&CLASSE=

$\mathrm{ADI} \% 2 \mathrm{DMC} \&$ cod_classe $=555 \& O R I G E M=I T \& R E C U R S O=0 \& T I P \_J U L G A M E N T O=M \& E M E N T A=2219>$. Acesso em: 24 ago. 2005.

5 "Princípio 1: O homem tem o direito fundamental à liberdade, à igualdade e ao desfrute de condições de vida adequadas, em um meio ambiente de qualidade tal que lhe permita levar uma vida digna, gozar de bem-estar e é portador solene de obrigação de proteger e melhorar o meio ambiente, para as gerações presentes e futuras. [...].” SILVA, Geraldo Eulálio do Nascimento. Direito ambiental internacional. 2. ed. rev. e atual. Rio de Janeiro: Thex, 2002. p. 322.

PRISMAS: Dir., Pol.Pub. e Mundial., Brasília, v.3, n, 2, p 288- 311, jul/dez.2006 
fundamental da pessoa humana, que se configura, "na verdade, como extensão do direito à vida, quer sobre o enfoque da própria existência física e saúde dos seres humanos"6, quer sobre o aspecto da qualidade de vida.

José Afonso da Silva acrescenta que o disposto no artigo 225 contempla normas distintas, sendo que no caput "se inscreve a norma-princípio, a norma-matriz, substancialmente reveladora do direito de todos ao meio ambiente ecologicamente equilibrado", enquanto "direito fundamental entre os direitos sociais do Homem, com sua característica de direitos a serem realizados e direitos a não serem perturbados. ${ }^{8}$ Em sentido semelhante, Nicolao Dino acrescenta que "esse traço de "fundamentalidade" reporta-se ao reconhecimento de que o direito ao ambiente sadio constitui a expressão de um valor inerente à dignidade humana." 9

Paulo de Bessa Antunes defende que o direito em comento é um direito fundamental da pessoa humana, de eficácia plena ${ }^{10}$, como importante marco na construção de uma sociedade democrática e participativa e socialmente solidária. Destaca que:

[...] o legislador constituinte, ao atribuir ao meio ambiente a condição de um direito a ser desfrutado pelo Ser Humano, desta e de outras gerações, efetivamente, deu-lhe uma conotação essencialmente política e, portanto, cultural. Diante da constitucionalização do termo, qualquer outra definição que exclua dele o caráter de um direito fundamental, a ser desfrutado pelos indivíduos, não encontra amparo em nossa Norma Fundamental. ${ }^{11}$

\footnotetext{
${ }^{6}$ MILARÉ, Edis. Direito do ambiente: doutrina, jurisprudência, glossário. 4 ed. rev. atual. e ampl. São Paulo: Revista dos Tribunais, 2005. p. 158. Ainda nesse sentido: "Esse novo direito fundamental, reconhecido pela Conferência das Nações Unidas sobre o Ambiente Humano de 1972 (Princípio 1), reafirmado pela Declaração do Rio sobre o Meio Ambiente e Desenvolvimento de 1992 (Princípio 1) e pela Carta da Terra de 1997 (Princípio 4), vem conquistando espaço nas constituições modernas, como, por exemplo, as de Portugal, de 1976, e Espanha, de 1978." Ibid., p. 158.

${ }^{7}$ SILVA, José Afonso da. Direito ambiental constitucional. 5. ed. São Paulo: Malheiros, 2004. p. 52.

${ }^{8}$ Ibid., p. 70.

${ }^{9}$ COSTA NETO, Nicolao Dino de Castro. Proteção jurídica do meio ambiente: I florestas. Belo Horizonte: Del Rey, 2003. p. 11. Ademais, ele ressalta que tal direito é corolário do direito à vida e que "não se esqueça, com efeito, de que o direito ao meio ambiente sadio e ecologicamente equilibrado constitui um direito e uma garantia fundamental, pois embora o preceito do art. 225, caput, não se ache inserido topologicamente no Título II, Capítulo I, da Constituição Federal, incide o disposto no art. $5^{\circ}, \S 1^{\circ}$, conferindo-lhe aplicação imediata." Ibid., p. 124.

${ }^{10}$ ANTUNES, Paulo de Bessa. Direito ambiental. 7 ed. rev., ampl. e atual. Rio de Janeiro: Lúmen Júris, 2004. p. 70-71. E ao mencionar o artigo 5, LXXIII (da ação popular), ressaltar que "Como é elementar, o artigo $5^{\circ}$ da Constituição Federal cuida dos direitos e garantias fundamentais. Ora, se é uma garantia fundamental do cidadão a existência de uma ação constitucional com a finalidade de defesa do meio ambiente, tal fato ocorre em razão de que o direito ao desfrute das condições saudáveis do meio ambiente é, efetivamente, um direito fundamental do ser humano." Ibid., p. 25

${ }^{11}$ Ibid., p. 156

PRISMAS: Dir., Pol.Pub. e Mundial., Brasília, v.3, n, 2, p 288- 311, jul/dez.2006 
Luis Sirvinkas, apoiado na classificação de norma-princípio de José Afonso da Silva, defende que, ainda que não expresso no artigo $5^{\circ}, \mathrm{CF}$, trata-se de um direito fundamental, um direito ou interesse difuso, a ser protegido e usufruído por todos. ${ }^{12}$

Entre outros, o que se ilustrou aqui foi que, em termos gerais, há uma reivindicação do direito em análise como direito fundamental, fundamentando-se, primordialmente, nas características que tal direito possui por compor a terceira geração de direitos fundamentais, quer dizer: historicidade, inalienabilidade/indisponibilidade, constitucionalização, vinculação aos Poderes Públicos, bem como um direito que propugna um interesse difuso, vinculado a um princípio de solidariedade, por exemplo.

Contudo, ainda que presentes neste direito algumas características inerentes aos direitos fundamentais ${ }^{13}$, não se esclarece suficientemente seu status, em termos da classificação funcional da moderna dogmática de direitos fundamentais. Há, quando muito, afirmação genérica e pouco fundamentada, de que se trata de um direito social (José Afonso da Silva, por exemplo), não ressaltando sua complexidade.

E a condição do direito ao meio ambiente como direito fundamental, ainda que louvável do ponto de vista argumentativo para $\mathrm{o}$ fortalecimento dos valores constitucionalmente protegidos, deve buscar maior coerência e fortalecimento no campo da dogmática dos direitos fundamentais, que podem ser alcançados, por exemplo, com maior reflexão crítica a partir de um maior desenvolvimento do cotejo entre este direito e os conceitos que buscam definir e classificar os direitos fundamentais. Uma sugestão desse caminho será apresentada a seguir, após a delimitação do que seja o bem jurídico ambiental, protegido constitucionalmente (conforme a doutrina majoritária de direito ambiental).

Breve análise do bem jurídico que o direito ao meio ambiente ecologicamente equilibrado visa proteger

Não há dúvida que o bem jurídico protegido por tal direito é extremamente relevante. Luis Roberto Barroso, ao analisar a proteção do meio ambiente na Constituição de 1988, destacou:

[...] por certo que existe um valor novo na ordem jurídica, representado pela preservação do meio ambiente. Este bem jurídico é tutelado por institutos e

\footnotetext{
${ }^{12}$ SIRVINKAS, Luís Paulo. Manual de direito ambiental. 3 ed. rev. e atual. São Paulo: Saraiva, 2005. p. 45

${ }^{13}$ Sobre as diversas características dos direitos fundamentais, cf. MENDES, Gilmar F.; COELHO, Inocêncio M.; BRANCO, Paulo G. G. Hermenêutica constitucional e direitos fundamentais. Brasília: Brasília Jurídica, 2000. p. 118-136 
normas que se espalham por diferentes domínios jurídicos, como o direito constitucional $[\ldots]^{14}$

E complementa José Afonso da Silva que "a tutela do meio ambiente é instrumental, no sentido de que, através dela, o que se protege é um valor maior: a qualidade de vida" 15 Edis Milaré ressalta, por fim, que "a Carta brasileira erigiu-o à categoria de um daqueles valores ideais da ordem social [...] e lhe dá a natureza de bem de uso comum do povo e essencial à sadia qualidade de vida [...]."16

Em verdade, o bem jurídico que se almeja proteger pode ser tanto a qualidade de vida $^{17}$, quanto o meio ambiente sadio ${ }^{18}$. Há quem diga, inclusive, que se trata de um bem que requer uma classificação doutrinária alternativa, qual seja, a de um bem difuso ${ }^{19}$, no sentido de que não é nem público (como bem estatal), nem privado (no sentido de ser usufruído individualmente). Resta claro, pois, que há certas peculiaridades acerca do bem jurídico protegido, devido, essencialmente, às características próprias e complexas de um direito de terceira geração.

${ }^{14}$ BARROSO, Luis Roberto. A proteção do meio ambiente na Constituição brasileira. Revista Forense, Rio de Janeiro, v. 317, p. 163, jan./mar. 1992.

${ }^{15}$ SILVA, José Afonso da. Direito ambiental constitucional. 5. ed. São Paulo: Malheiros, 2004. p. 70

${ }^{16}$ MILARÉ, Edis. Direito do ambiente: doutrina, jurisprudência, glossário. 4 ed. rev. atual. e ampl. São Paulo: Revista dos Tribunais, 2005. p. 186

17 "O bem ambiental é, portanto, um bem que tem como característica constitucional mais relevante ser ESSENCIAL À SADIA QUALIDADE DE VIDA, sendo ontologicamente de uso comum do povo, podendo ser desfrutado por toda e qualquer pessoa dentro dos limites constitucionais. Uma vida saudável reclama a satisfação de um dos fundamentos democráticos de nossa Constituição Federal, qual seja, a dignidade da pessoa humana, conforme dispõe o art. $1^{\circ}$, III. É, portanto, da somatória dos dois aspectos: bem de uso comum do povo e essencial à sadia qualidade de vida, que estrutura constitucionalmente o bem ambiental." FIORILlO, Celso Antônio Pacheco. Curso de direito ambiental brasileiro. 5 ed. ampl. São Paulo: Saraiva, 2004.p. 51

${ }^{18}$ A discussão sobre a delimitação do bem ambiental passa, inclusive, pelo embate de uma visão antropocêntrica ou ecocêntrica/biocêntrica de meio ambiente. Para um maior esclarecimento a esse respeito, consultar: SIRVINKAS, Luís Paulo. Manual de direito ambiental. 3 ed. rev. e atual. São Paulo: Saraiva, 2005. p. 08 et seq.

${ }^{19}$ Nesse sentido, ressalta Luis Sirvinkas que: "O bem ambiental, por essa razão, não pode ser classificado como bem público nem como bem privado (artigo 98 do CC/2002), ficando numa faixa intermediária denominada bem difuso. Difuso é o bem que pertence a cada um e, ao mesmo tempo, a todos. Não há como identificar o seu titular e seu objeto é insuscetível de divisão. Ibid., p. 32.

PRISMAS: Dir., Pol.Pub. e Mundial., Brasília, v.3, n, 2, p 288- 311, jul/dez.2006 


\section{O direito ao meio ambiente ecologicamente equilibrado sob a perspectiva da dogmática de direitos fundamentais}

A tentativa de melhor delimitar este direito, a partir do seu confronto com a classificação funcional dos direitos fundamentais

É assente na doutrina atual de direitos fundamentais o entendimento de que os direitos fundamentais desempenham múltiplas funções na sociedade e na ordem jurídica ${ }^{20}$. Nesse sentido, Paulo Gustavo destaca que "essa diversidade de funções leva a que a própria estrutura dos direitos fundamentais não seja unívoca e propicia algumas classificações, úteis para a melhor compreensão do conteúdo e eficácia dos vários direitos. ${ }^{21}$

Tal perspectiva remonta aos fundamentos da clássica teoria dos quatro status de Jellinek $^{22}$, depurando-a e desenvolvendo-a ao longo do tempo, de forma a poder melhor realçar as espécies de direitos fundamentais mais freqüentemente mencionadas, quais sejam: "direitos de defesa (ou direitos de liberdade) e direitos a prestações (ou direitos cívicos). A essas duas espécies alguns acrescentam a dos direitos de participação.",23

De forma semelhante, Ingo Sarlet defende que uma proposta classificatória constitucionalmente adequada dos direitos fundamentais pode ter como ponto de partida o critério das funções por eles exercidas (segundo ele, com base na proposição de Alexy) dividindo tais direitos em dois grandes grupos:

[...] os direitos fundamentais na condição de direitos de defesa e os direitos fundamentais como direitos a prestações (de natureza fática e jurídica). $\mathbf{O}$ segundo grupo (dos direitos prestacionais), dividir-se-ia igualmente em dois subgrupos, quais sejam, o dos direitos de prestações em sentido amplo (englobando, por sua vez, os direitos de proteção e os direitos à participação na organização e no procedimento) e os direitos a prestações em sentido estrito (direitos a prestações materiais sociais) $[\ldots]{ }^{24}$ [grifo nosso]

Aceitando tal proposta como fio condutor, busca-se analisar o direito ao meio ambiente em face de cada categoria classificatória, de forma a fortalecer a afirmação de sua

\footnotetext{
20 “A constatação da multifuncionalidade dos direitos fundamentais não constitui, por outro lado, nenhuma novidade e pode - a despeito de novos direitos e importantes desdobramentos vinculados às perspectivas subjetiva e objetiva - ser reconduzida à doutrina dos quatro status de G. Jellinek, do final do século passado, onde encontra sua vertente, tendo sido, além disso (inclusive entre nós), utilizada recentemente como referencial para a classificação dos direito fundamentais." SARLET, Ingo Wolfgang. A eficácia dos direitos fundamentais. 5. ed. rev. atual. e ampl. Porto Alegre: Livraria do Advogado, 2005. p. 171

${ }^{21}$ MENDES, Gilmar F.; COELHO, Inocêncio M.; BRANCO, Paulo G. G. Hermenêutica constitucional e direitos fundamentais. Brasília: Brasília Jurídica, 2000. p. 139

${ }^{22}$ Para uma analise crítica desta teoria, cf. ALEXY, Robert. Teoria de los derechos fundamentales. Trad. Ernesto Garzón Valdés. Madrid: Centro de Estudios Constitucionales, 1993. cap. 5.

${ }^{23}$ MENDES; COELHO; BRANCO, op. cit., p. 140.

${ }^{24}$ SARLET, Ingo Wolfgang. A eficácia dos direitos fundamentais. 5. ed. rev. atual. e ampl. Porto Alegre: Livraria do Advogado, 2005. p. 185

PRISMAS: Dir., Pol.Pub. e Mundial., Brasília, v.3, n, 2, p 288- 311, jul/dez.2006 
fundamentalidade. Os direitos de defesa caracterizam-se pela imposição de um dever de abstenção do Estado na esfera de liberdade individual do indivíduo, contendo "disposições definidoras de uma competência negativa do Poder Público (negative Kompetenzbestimmung)" $)^{\text {,25. }}$.

Assim, resta claro que a liberdade protegida é individualmente considerada (titularidade individual), de forma a dificultar a possibilidade de inserção do direito ao meio ambiente sadio nesta espécie de direitos fundamentais, pois este veicula uma titularidade coletiva, enquanto bem de caráter coletivo e dotado de transindividualidade, de modo que não pode ser individualmente desfrutado. Os direitos de defesa "vinculam-se diretamente à concepção liberal do Estado de Direito,"26 buscando a manutenção do status quo do indivíduo. Portanto, ainda que haja um traço de defesa ou de abstenção de agressão ao meio ambiente (enquanto comportamento negativo), não se configura adequadamente o direito ao meio ambiente sadio como típico direito de defesa.

Por outro lado, os direitos fundamentais, como direitos a prestações ${ }^{27}$, "exigem que o Estado aja para atenuar desigualdades, com isso estabelecendo moldes para o futuro da sociedade." ${ }^{28}$ Nesse sentido, trata-se não de uma liberdade em face do Estado, "mas de desfrutar essa liberdade mediante a atuação do Estado (Freiheit durch...)."29

Subdivide-se tal grupo em dois subgrupos. O primeiro se refere aos direitos de prestação em sentido amplo, ou seja, direitos a prestações jurídicas. Nesse sentido, “o objeto do direito será a normação pelo Estado do bem jurídico protegido constitucionalmente.”30 Tais prestações consistiriam na formulação de normas de organização e procedimento "que dependem, na sua realização, tanto de providências estatais com vistas à criação e conformação de órgãos, setores ou repartições, como de outras, de índole normativa [...].”31

${ }^{25}$ MENDES, Gilmar Ferreira. Direitos fundamentais e controle de constitucionalidade: estudos de direito constitucional. 3 ed. rev. e ampl. São Paulo: Saraiva, 2004. p. 02

${ }^{26}$ SILVA, Christine Oliveira Peter da. Hermenêutica de direitos fundamentais: uma proposta constitucionalmente adequada. Brasília: Brasília Jurídica, 2005. p. 89. Ainda sobre tais direitos, a autora destaca que "Na constituição de 1988, os direitos de defesa são encontrados sob diversos títulos: direitos individuais, direitos coletivos, direitos individuais de expressão coletiva, direitos sociais, direitos à nacionalidade e à cidadania e garantias fundamentais. Assim sendo, deve-se rechaçar qualquer intenção de fazer corresponder a função de direito de defesa com qualquer um destes títulos.” Ibid., p. 90

${ }^{27}$ SARLET, op. cit., p. 205

${ }^{28}$ MENDES, Gilmar F.; COELHO, Inocêncio M.; BRANCO, Paulo G. G. Hermenêutica constitucional e direitos fundamentais. Brasília: Brasília Jurídica, 2000. p. 142-143

${ }^{29}$ MENDES, Gilmar Ferreira. Direitos Fundamentais e controle de constitucionalidade: estudos de direito constitucional. 3 ed. rev. e ampl. São Paulo: Saraiva, 2004. p. 06.

${ }^{30}$ MENDES, Gilmar F.; COELHO, Inocêncio M.; BRANCO, Paulo G. G. Hermenêutica constitucional e direitos fundamentais. Brasília: Brasília Jurídica, 2000. p. 143.

${ }^{31}$ MENDES, op. cit., p. 08.

PRISMAS: Dir., Pol.Pub. e Mundial., Brasília, v.3, n, 2, p 288- 311, jul/dez.2006 
Portanto, parece claro que não há uma coincidência exata do bem jurídico ambiental e do bem jurídico protegido por tais normas de prestação em sentido amplo.

Quanto ao segundo subgrupo, referente aos direitos de proteção, estes podem ser conceituados "como posições jurídicas fundamentais que outorgam ao indivíduo o direito de exigir do Estado que este os proteja contra ingerências de terceiros em determinados bens pessoais." ${ }^{~} 2$ Vê-se que, pela dimensão de proteção de bens pessoais, afasta-se a possibilidade de adequação do já mencionado bem ambiental, enquanto bem de titularidade coletiva e de caráter difuso (transindividual) e, conseqüentemente, do direito ao meio ambiente sadio nesta categoria.

A respeito dos direitos a prestações positivas em sentido estrito ou dos direitos a prestações materiais, ressalta-se que resultam da concepção social do Estado de Direito, concebidos como direitos sociais por excelência. Nesse sentido, "são direitos devidos pelo Estado, embora, nessa esfera dos direitos fundamentais, os particulares também estejam vinculados, em especial, quanto aos direitos dos trabalhadores [...]."33 $\mathrm{Na}$ verdade, estão ligados a um conceito de justiça material, na busca de realização da igualdade e da liberdade reais. Desta forma, estariam direcionados por uma adequada e justa distribuição dos bens existentes. O bem jurídico ambiental, contudo, não pode ser distribuído a uns e a outros individualmente ou coletivamente (em grupos específicos) na busca de uma adequação material, pois indivisível e de titularidade coletiva e transindividual, de antemão. Portanto, parece também não figurar tão bem nesta seara.

Por fim, quanto à classificação de direitos de participação, há autores que os qualificam como direitos fundamentais "orientados a garantir a participação dos cidadãos na formação da vontade do país. Corresponderia ao capítulo da Constituição Federal relativo aos direitos políticos, no Título dos Direitos Fundamentais. ${ }^{34}$ Nesse caso, também parece claro que não será adequada a classificação do direito ao meio ambiente sadio enquanto direito de participação.

\footnotetext{
32 SILVA, Christine Oliveira Peter da. Hermenêutica de direitos fundamentais: uma proposta constitucionalmente adequada. Brasília: Brasília Jurídica, 2005. p. 99.

${ }^{33}$ MENDES; COELHO; BRANCO, op. cit., p. 145. Ademais, ele destaca que: "podem ser extraídos exemplos de direitos a prestação material dos direitos sociais enumerados no art. $6^{\circ}$ da constituição - o direito à educação, à saúde, ao trabalho, ao lazer, à segurança, à previdência social, à proteção da maternidade, à infância e o direitos dos desamparados à assistência." Ibid., p. 145.

${ }^{34}$ MENDES, Gilmar F.; COELHO, Inocêncio M.; BRANCO, Paulo G. G. Hermenêutica constitucional e direitos fundamentais. Brasília: Brasília Jurídica, 2000. p. 150. 
Resta a seguinte questão, diante da dogmática dos direitos fundamentais: como enquadrar o direito em análise nesta perspectiva classificatória ou, ainda, deve isto ser feito? E como? ${ }^{35}$

Paulo Gustavo ressalta que o direito à qualidade do meio ambiente, enquanto direito de terceira geração, dirige-se à proteção não do homem isoladamente, mas de coletividades, considerado direito de titularidade difusa ou coletiva. Destaca que "a situação dessas reivindicações ${ }^{36}$ como direito fundamentais tem sido objeto de questionamento doutrinário, quer pelo caráter vago do seu conteúdo, quer porque a titularidade deles recai sobre o Estado ou a nação, causando estranheza." ${ }^{37}$ Mas não obstante tais controvérsias, segundo ele, o Supremo Tribunal Federal tem destacado em alguns arestos a referência ao direito ao meio ambiente ecologicamente equilibrado como consagração de uma terceira geração de direitos fundamentais, entre nós, o estabelecido no artigo 225, caput, da Constituição. $^{38}$

Noutro momento o referido autor, ao tratar das normas decorrentes do regime democrático e dos princípios que regem a constituição - com destaque ao disposto no artigo $5^{\circ}, \S 2^{\circ}, \mathrm{CF}$, e da possibilidade expressa de existência em nossa ordem jurídica de um sistema aberto de direitos fundamentais (em que há direitos fundamentais fora do catálogo do Título II), afirma que "no âmbito dos direitos sociais, seriam direitos fundamentais fora do catálogo os direitos à previdência social e à assistência social e o direito à proteção do meio ambiente (artigo 225) - este último já mencionado no STF como direito fundamental." 39 Contudo, tal hipótese assim não foi tratada claramente no seu estudo sobre direitos a prestações (que, em regra, identificam-se mais com as características dos direitos sociais).

Por sua vez, Ingo Sarlet indica que a nota distintiva dos direitos de terceira geração está na titularidade coletiva, por vezes indefinida e indeterminável, o que se demonstra, por exemplo, "especialmente no direito ao meio ambiente e qualidade de vida, o

\footnotetext{
${ }^{35}$ E esta indagação se mostra pertinente e pendente, no sentido de que não se consegue formatar ou enquadrar facilmente ou de modo conveniente o direito em análise, de forma clara e adequada, à classificação proposta como um todo. Há características que o aproxima, tão somente, a uma ou outra categoria de classificação.

${ }^{36}$ Reivindicações de direitos de terceira geração como direitos fundamentais.

${ }^{37}$ MENDES; COELHO; BRANCO, op. cit., p. 111.

${ }^{38}$ Segundo Paulo Gustavo Gonet, "Assim, lê-se no RE 134.297-8/SP (DJ 22.09.95), o rel. Min. Celso de Mello: "Direito ao meio ambiente ecologicamente equilibrado: a consagração constitucional de um típico direito de terceira geração (CF, art. 225, caput)". Da mesma forma, no MS 22.164-0/SP, rel. o Min. Celso de Mello, (DJ 17/11/95, 39206): “A questão do direito ao meio ambiente ecologicamente equilibrado. Direito de terceira geração. Princípio da solidariedade. [...] os direitos de terceira geração, que materializam poderes de titularidade coletiva atribuídos genericamente a todas as formações sociais, consagram o princípio da solidariedade e constituem um momento importante no processo de desenvolvimento, expansão e reconhecimento de direitos humanos, caracterizados, enquanto valores fundamentais indisponíveis, pela nota de uma essencial inexauribilidade"." [grifo nosso]. MENDES; COELHO; BRANCO, op. cit., p. 112.

${ }^{39}$ MENDES; COELHO; BRANCO, op. cit., p. 160-161

PRISMAS: Dir., Pol.Pub. e Mundial., Brasília, v.3, n, 2, p 288- 311, jul/dez.2006 
qual, em que pese ficar preservada a sua dimensão individual, reclama novas técnicas de garantia e proteção." ${ }^{40}$ Segue o autor a questionar que, entre estes direitos de terceira geração, por vezes, autores ${ }^{41}$ colocam "sérias dúvidas no que concerne à própria qualificação de grande parte destas reivindicações como autênticos direitos fundamentais.",42

É interessante notar, pois, que Ingo Sarlet defende a possibilidade de certa preservação ou adequação do direito ao meio ambiente ecologicamente equilibrado com um cunho individual, por estar, em última análise, ligado à "proteção da vida, da liberdade, da igualdade e da dignidade da pessoa humana." 43 Complementa, a respeito desse direito, que “em que pese a habitual (embora não-cogente) presença do interesse coletivo ou difuso, não deixa de objetivar a proteção da vida e da qualidade de vida do homem na sua individualidade. ${ }^{, 44}$ Desse modo, deixa claro que há certa pertinência dele com um caráter de direito fundamental como condição de defesa da proteção à vida. A respeito da dificuldade de delimitar tais direitos nas categorias usuais de direitos fundamentais, ressalta que:

Mesmo em se considerando a controvérsia que grassa em torno do reconhecimento do caráter de autênticos direitos fundamentais de alguns dos direitos da terceira e da quarta dimensões, de modo especial, contudo, no que diz com a possibilidade de sua efetivação como direitos subjetivos, não há como negligenciar a relevância também destas novas dimensões de direitos fundamentais, para o progresso da humanidade. ${ }^{45}$

A dificuldade de confirmação do direito ao meio ambiente ecologicamente equilibrado enquanto um direito fundamental, pela dogmática dos direitos fundamentais, diante das diversas peculiaridades que o acompanham, pode estar ligada a razões históricas interessantes. O desenvolvimento da dogmática dos direitos fundamentais pelo direito alemão, o qual trouxe imensa contribuição à dogmática geral dos direitos fundamentais e que se reverbera, também no Brasil, inclusive, para a classificação que ora se propôs a analisar neste artigo, tem como referência o fato de que

\footnotetext{
${ }^{40}$ SARLET, Ingo Wolfgang. A eficácia dos direitos fundamentais. 5. ed. rev. atual. e ampl. Porto Alegre: Livraria do Advogado, 2005. p. 57.

${ }^{41}$ Entretanto, destaca também o seguinte: "Para outros, por sua vez, os direitos fundamentais da terceira dimensão, [...], podem ser considerados uma resposta ao fenômeno denominado de "poluição das liberdades", que caracteriza o processo de erosão e degradação sofrido pelos direito e liberdades fundamentais, principalmente em face do uso de novas tecnologias. Nesta perspectiva, assumem especial relevância o direito ao meio ambiente e à qualidade de vida (que já foi considerado como direito de terceira geração pela corrente doutrinária que parte do critério da titularidade transindividual), [...]." SARLET, op. cit., p. 58.

${ }^{42}$ Ibid., p. 57.

${ }^{43}$ Ibid., p. 62.

${ }^{44}$ Ibid., p. 62.

${ }^{45}$ SARLET, Ingo Wolfgang. A eficácia dos direitos fundamentais. 5. ed. rev. atual. e ampl. Porto Alegre: Livraria do Advogado, 2005. p. 65.

PRISMAS: Dir., Pol.Pub. e Mundial., Brasília, v.3, n, 2, p 288- 311, jul/dez.2006 
Para a Lei Constitucional Federal de 1949, o ambiente não constituía, ainda, uma preocupação fundamental. Por isso, o seu texto, bem como as emendas que lhe foram sucessivamente introduzidas na década de 50, não contêm, além de competências legislativas específicas, disposições directamente vocacionadas para a protecção do meio ambiente. ${ }^{46}$

E tal constatação pode ter influenciado, sobremaneira, o (não) desenvolvimento da nota de fundamentalidade, que hoje se reivindica ao direito ao meio ambiente ecologicamente equilibrado, não só na Alemanha, mas em outros países que recebem seus influxos teóricos (sobretudo na seara de dogmática de direitos fundamentais). Não por menos, constata-se que a prática jurisprudencial do Tribunal Constitucional Federal alemão não ressalta o caráter fundamental deste direito, enquadrando-o como decorrência do desenvolvimento da cláusula do Estado Social de Direito. ${ }^{47}$

A seguir tal concepção, certo é, contudo, que o bem jurídico que ele protege é fundamental e consagra um valor constitucional essencial na constituição, que deve ser protegido e compatibilizado com outros valores constitucionais e direitos fundamentais.

Daí que, essa perspectiva - que consagra o meio ambiente como valor constitucional relevante (ou bem constitucional essencial a ser protegido), mas que não o considera um direito fundamental, pode ecoar com mais facilidade na doutrina de direitos fundamentais, até porque está permeada por uma série de condições sócio-econômicas e políticas mutáveis, a serem anteriormente analisadas e decididas.

Breve síntese da ocorrência da colisão do direito ao meio ambiente ecologicamente equilibrado com outros valores ou direitos fundamentais: o destaque ao direito de iniciativa econômica privada e ao direito de propriedade

A busca de maior precisão do direito ao meio ambiente ecologicamente equilibrado (e de sua fundamentabilidade) tem essencial relevância para uma melhor

\footnotetext{
${ }^{46}$ FERNANDEZ, Maria Elizabeth Moreira. Direito ao ambiente e propriedade privada: aproximação ao estudo da estrutura e das conseqüências das "leis-reserva" portadoras de vínculos ambientais. Coimbra: Coimbra, 2001. p. 19.

47 Nesse sentido, é esclarecedor e fundamental o magistério de Maria Fernandez, a saber: “Actualmente, a manifestação constitucional do direito ao meio ambiente é, ainda, bastante incipiente, pelo que tem cabido ao Tribunal Constitucional Federal Alemão, à lei e, em especial, aos regulamentos administrativos a tarefa de explicitar, convenientemente, o âmbito, o objeto, bem como a natureza deste recente ramo do direito. No que concerne à jurisprudência do Tribunal Constitucional Alemão, é curioso notar que este nega ao direito ao ambiente o carácter ou a natureza de direito fundamental, considerando que a obrigação de protecção desta realidade decorre, antes, do desenvolvimento da cláusula do Estado Social de Direito. $O$ Tribunal Constitucional, na ausência de uma clara manifestação do texto da Constituição, tem tentado concretizar o direito ao meio ambiente através do direito à vida e do direito à integridade física em conjugação constante com a garantia constitucional do direito de propriedade privada." [grifo nosso]. FERNANDEZ, Maria Elizabeth Moreira. Direito ao ambiente e propriedade privada: aproximação ao estudo da estrutura e das conseqüências das "leis-reserva" portadoras de vínculos ambientais. Coimbra: Coimbra, 2001. p. 20
} 
compreensão das tensões constitucionais e das soluções que a elas se apresentam. Nesse sentido, o caso que serve como pano de fundo deste artigo ilustra bem a questão, ao mencionar em sua ementa ${ }^{48}$ a possibilidade de um estado de tensão entre valores constitucionalmente relevantes, relacionando tanto a economia (artigo 3, II c/c artigo 170, VI, $\mathrm{CF}$ ) e ecologia (artigo 225, CF), que não se resolve com o aniquilamento de um em favor de outro, mas a partir de uma harmonização de tais princípios ${ }^{49}$.

Ressalte-se, que este é, certamente, um dos campos mais comuns em que tensões envolvendo o direito ao meio ambiente podem surgir. Até porque a busca do desenvolvimento sustentável passa pelo balanceamento do desenvolvimento econômico e da preservação do meio ambiente e da qualidade de vida. ${ }^{50}$

A configuração do direito ao meio ambiente como direito fundamental ou somente como bem (ou valor) constitucionalmente relevante (embora não configurando um direito fundamental) pode ensejar a sua análise sob perspectivas distintas do fenômeno de colisão de direitos, segundo a diferenciação atual da dogmática de direitos fundamentais, que apresenta duas hipóteses: colisão de direitos em sentido amplo e colisão de direitos em sentido estrito. "As colisões em sentido estrito referem-se apenas àqueles conflitos entre direitos fundamentais" ${ }^{, 51}$, envolvendo direitos idênticos ou diversos. De modo distinto, afirma-

\footnotetext{
48 "Relações entre economia (cf, art. 3, ii, c/c o art. 170, vi) e ecologia (cf, art. 225) - colisão de direitos fundamentais - critérios de superação desse estado de tensão entre valores constitucionais relevantes - os direitos básicos da pessoa humana e as sucessivas gerações (fases ou dimensões) de direitos - a questão da precedência do direito à preservação do meio ambiente: uma limitação constitucional explícita à atividade econômica (cf, art. 170, vi) [...] a preservação da integridade do meio ambiente: expressão constitucional de um direito fundamental que assiste à generalidade das pessoas [...] a atividade econômica não pode ser exercida em desarmonia com os princípios destinados a tornar efetiva a proteção ao meio ambiente [...]. A questão do desenvolvimento nacional (cf, art. $3^{\circ}$, ii) e a necessidade de preservação da integridade do meio ambiente (cf, art. 225): o princípio do desenvolvimento sustentável como fator de obtenção do justo equilíbrio entre as exigências da economia e as da ecologia." [grifo nosso]. BRASIL. Supremo Tribunal Federal. Medida Cautelar em Ação Direta de Inconstitucionalidade 3.540-1 - Distrito Federal (ADI 3.540 - MC/DF). Relator: Ministro Celso de Melo. Julgado em 01 de setembro de 2005. Diário de Justiça, Brasília, 03 fev. 2006. Disponível em: $<$ http://www.stf.gov.br/jurisprudencia/IT/frame.asp? $\mathrm{PROCESSO}=3540 \& C L A S S E=\mathrm{ADI} \% 2 \mathrm{DMC} \&$ cod_classe $=555 \& O R I G E M=I T \& R E C U R S O=0 \& T I P \_J U L G A$ MENTO=M\&EMENTA=2219>. Acesso em: 24 ago. 2005.

${ }^{49}$ Quando ocorre um conflito entre dois princípios, como quando um princípio informa que algo está permitido e o outro informa que algo está proibido, um dos princípios deve ceder ao outro. Nesse sentido, destaca Alexy: "Pero, esto no significa declarar inválido al principio desplazado ni que el principio desplazado haya que introducir una cláusula de excepción. Más bien lo que sucede es que, bajo ciertas circunstancias uno de los princípios precede al otro. Bajo otras circunstancias, la cuestión de la precedencia puede ser solucionada de manera inversa." ALEXY, Robert. Teoria de los derechos fundamentales. Trad. Ernesto Garzón Valdés. Madrid: Centro de Estudios Constitucionales, 1993. p. 89

50 Cf. SILVA, Christine Oliveira Peter da. Hermenêutica de direitos fundamentais: uma proposta constitucionalmente adequada. Brasília: Brasília Jurídica, 2005. p. 26-27.

${ }^{51}$ MENDES, Gilmar Ferreira. Direitos fundamentais e controle de constitucionalidade: estudos de direito constitucional. 3 ed. rev. e ampl. São Paulo: Saraiva, 2004. p. 78

PRISMAS: Dir., Pol.Pub. e Mundial., Brasília, v.3, n, 2, p 288- 311, jul/dez.2006 
se que "as colisões em sentido amplo envolvem os direitos fundamentais e outros princípios ou valores que tenham por escopo a proteção de interesses da comunidade. ${ }^{, 52}$

Caso se considere o direito ao meio ambiente como direito fundamental, terão que ser desenvolvidos parâmetros que permitam sua acomodação em colisões em sentido estrito. Diferentemente, caso assim não se considere, a discussão acerca de tensões que envolvam o direito ao meio ambiente ecologicamente equilibrado ficará no âmbito das colisões em sentido amplo $^{53}$, pois tal direito não consagraria um direito fundamental, mas somente um valor constitucional relevante a ser protegido.

Essa última posição parece ser bem aceita por doutrinadores da dogmática de direitos fundamentais. Nesse sentido, parece orientar o entendimento, por exemplo, de Gilmar Mendes, ao lecionar sobre as colisões de direitos em sentido amplo, a envolver:

[...] direitos fundamentais e outros valores constitucionalmente relevantes. Assim, é comum a colisão entre o direito de propriedade e interesses coletivos associados, v. g., à utilização da água ou mesmo à defesa de um meio ambiente equilibrado." ${ }^{54}$ [grifo nosso]

O campo de tensão entre o direito de propriedade e o de defesa do meio ambiente equilibrado é outro extremamente rico em exemplos férteis para a análise da existência e da forma de resolução de colisões. Não por menos, tem despertado interesse de diversos doutrinadores do direito ambiental ${ }^{55}$ e do direito constitucional, ${ }^{56}$ principalmente, porque tais

\footnotetext{
52 Ibid., p. 78

${ }^{53}$ Vale ressaltar que toda a problemática dos tipos de colisão passa por diversas depurações e opções teóricas, a depender do modelo a que se vincula; isto, contudo, foge ao escopo deste artigo. Porém, para um maior aprofundamento nesse sentido, cf. ALEXY, Robert. Teoria de los derechos fundamentales. Trad. Ernesto Garzón Valdés. Madrid: Centro de Estudios Constitucionales, 1993.

${ }^{54}$ MENDES, Gilmar F.; COELHO, Inocêncio M.; BRANCO, Paulo G. G. Hermenêutica constitucional e direitos fundamentais. Brasília: Brasília Jurídica, 2000. p. 282.

${ }^{55}$ Nesse sentido é que Maria Fernandez apresenta o escopo de sua pesquisa: "Contudo, a proteção da natureza, a prossecução do equilíbrio ecológico e a conservação do patrimônio artístico e cultural de determinado país, ou seja, a pressecução de uma determinada teleologia político-ambiental, implica, inexpugnavelmente, a colisão com outros valores, direitos ou interesses juridicamente tutelados pela nossa Lei Fundamental. O objecto central do presente trabalho debruça-se, exactamente, sobre uma das relações conflituais que a introdução constitucional da teleologia ambiental é susceptível de provocar. Trata-se da tensão existente entre ambiente $e$ propriedade privada." FERNANDEZ, Maria Elizabeth Moreira. Direito ao ambiente e propriedade privada: aproximação ao estudo da estrutura e das conseqüências das "leis-reserva" portadoras de vínculos ambientais. Coimbra: Coimbra, 2001. p. 09.

${ }^{56}$ Um exemplo extremamente interessante é o caso estudado por Canotilho em obra específica, intitulada "Proteção do ambiente e direito de propriedade". Nesse livro analisa o caso da Quinta do Taipal, que tem a sua relevância por ele destacada: "O caso da $<<$ Quinta do Taipal $>>$ discutido e decidido nestes cinco arestos jurisdicionais pode e deve considerar-se um leading case da jurisprudência ambientalista portuguesa. Resolvemos anotar conjuntamente todos os Acórdãos em referência, porque, deste modo, podemos fazer um levantamento topográfico mais pormenorizado do conflito e, ao mesmo tempo, registrar o balanceamento de direitos $e$ interesses agitados nas várias instâncias jurisdicionais chamadas a fazer o direito na hipótese sub judice." [grifo nosso]. CANOTILHO, José J. Gomes. Protecção do ambiente e direito de propriedade: crítica de jurisprudência ambiental. Coimbra: Coimbra, 1995. p. 81.
} 
exemplos podem ser objeto de resolução a partir de uma ponderação de bens nos casos concretos, como ocorre, também, no caso pano de fundo deste artigo ${ }^{57}$.

\section{Um breve olhar acerca da perspectiva portuguesa do direito ao meio ambiente ecologicamente equilibrado.}

O direito constitucional português traz grande contribuição acerca do debate da fundamentabilidade do direito ao meio ambiente ecologicamente equilibrado, posto que, "ao contrário do que sucede noutros ordenamentos jurídico-constitucionais, nomeadamente europeus, como o italiano, o alemão e o espanhol", a Constituição portuguesa albergou, inequivocamente, os valores ambientais, ao positivar, em seu artigo 66, o direito ao ambiente $^{58}$. Além disso, a fórmula constitucional de disposição desse direito é muito semelhante à formula prevista no artigo 225 da constituição brasileira de 1988. Maria Fernandez assevera que:

O direito ao meio ambiente não se reconduz, pois, na nossa Lei Fundamental, a uma simples manifestação ou expressão do direito de personalidade, nem tão espelha uma vertente específica do direito à saúde, assumindo, pelo contrário, num esforço marcadamente juspublicístico, um

\footnotetext{
${ }^{57}$ Ressalte-se trecho do voto do Ministro Relator Celso de Mello: "Isso significa, portanto, Senhor Presidente, que a superação dos antagonismos existentes entre princípios e valores constitucionais há de resultar da utilização de critérios que permitam, ao Poder Público (e, portanto, aos magistrados e Tribunais), ponderar e avaliar, "hic et nunc", em função de determinado contexto e sob uma perspectiva axiológica concreta, qual deva ser o direito a preponderar no caso, considerada a situação de conflito ocorrente, desde que, no entanto - tal como adverte o magistério da doutrina na análise da delicadíssima questão pertinente ao tema da colisão de direitos [...], a utilização do método da ponderação de bens e interesses não importe em esvaziamento do conteúdo essencial dos direitos fundamentais, dentre os quais avulta, por sua significativa importância, o direito à preservação do meio ambiente." [grifo nosso]. BRASIL. Supremo Tribunal Federal. Medida Cautelar em Ação Direta de Inconstitucionalidade 3.540-1 - Distrito Federal (ADI 3.540 - MC/DF). Relator: Ministro Celso de Melo. Julgado em 01 de setembro de 2005. Diário de Justiça, Brasília, 03 fev. 2006. Disponível em: <http:/www.stf.gov.br/jurisprudencia/IT/frame.asp? PROCESSO $=3540 \& C L A S S E=A D I \% 2 D M C \&$ cod_classe $=555 \& O R I G E M=I T \& R E C U R S O=0 \& T I P$ JULGA MENTO=M\&EMENTA=2219>. Acesso em: 24 ago. 2005.

58 “Artigo 66. (Ambiente e qualidade de vida) 1. Todos têm direito a um ambiente de vida humano, sadio e ecologicamente equilibrado e o dever de o defender. 2. Para assegurar o direito ao ambiente, no quadro de um desenvolvimento sustentável, incumbe ao Estado, por meio de organismos próprios e com o envolvimento e a participação dos cidadãos: a) Prevenir e controlar a poluição e os seus efeitos e as formas prejudiciais de erosão; b) Ordenar e promover o ordenamento do território, tendo em vista uma correcta localização das actividades, um equilibrado desenvolvimento sócio-económico e a valorização da paisagem; c) Criar e desenvolver reservas e parques naturais e de recreio, bem como classificar e proteger paisagens e sítios, de modo a garantir a conservação da natureza e a preservação de valores culturais de interesse histórico ou artístico; d) Promover o aproveitamento racional dos recursos naturais, salvaguardando a sua capacidade de renovação e a estabilidade ecológica, com respeito pelo princípio da solidariedade entre gerações; e) Promover, em colaboração com as autarquias locais, a qualidade ambiental das povoações e da vida urbana, designadamente no plano arquitectónico e da protecção das zonas históricas; f) Promover a integração de objectivos ambientais nas várias políticas de âmbito sectorial; g) Promover a educação ambiental e o respeito pelos valores do ambiente; h) Assegurar que a política fiscal compatibilize desenvolvimento com protecção do ambiente e qualidade de vida." PORTUGAL. Constituição da República Portuguesa (promulgação em 02.04.1976 e entrada em vigor em 25.04.1976). VII Revisão Constitucional [2005]. Disponível em: $<$ http://www.parlamento.pt/const_leg/crp_port/>. Acesso em: 24 ago. 2005.
} 
estatuto jurídico-constitucional autônomo, não podendo, por via disso, ser encarado apenas como um simples "preceito-fim", nem como um direito fundamental por derivação de outros direitos fundamentais jurídicoconstitucionalmente consagrados. O legislador constituinte revestiu, de modo inequívoco, o direito ao ambiente do estatuto de direito formal e materialmente constitucional. ${ }^{59}$

Jorge Miranda destaca que, em sumária análise do direito comparado, é possível destacar algumas características que acompanham esse direito, a saber: o fato de ser recente sua manifestação (quase só depois do final da segunda guerra mundial), a presença de duas fases mais ou menos delimitadas (antes de 1970 - fórmulas muito genéricas e após 1970 maior precisão dos preceitos e incumbências do Estado), presença em constituições dos mais diversos regimes e localização preponderante em sede de direitos fundamentais e de Constituição econômica. ${ }^{60}$

Contudo, ao analisar os dispositivos referentes a tal direito na constituição portuguesa, considera que o tratamento constitucional atual do meio ambiente consiste numa dupla consideração:

[...] quer a nível de <tarefas fundamentais $>$ do Estado (art. 9, alínea e), quer a nível de direitos fundamentais (art. 66, principalmente); portanto, quer dum prisma objectivo e organizativo, quer dum prisma subjectivo e definitório de relações entre as pessoas e a comunidade política. ${ }^{61}$

Aprofundando a possibilidade de assimilação deste direito como fundamental, Jorge Miranda assevera que tal mister só é possível com base na premissa de que "o direito ao ambiente tem de ser percebido numa perspectiva de complexidade e de multifuncionalidade." ${ }^{22}$ Nessa perspectiva de multifuncionalidade, Jorge Miranda ressalta que, apesar de localizado topograficamente junto aos Direitos e Deveres Sociais, "o direito ao ambiente não suscita só, nem talvez primordialmente, direitos econômicos, sociais e culturais. Conduz, outrossim a direitos, liberdades e garantias ou a direitos de natureza análoga."63

\footnotetext{
59 FERNANDEZ, Maria Elizabeth Moreira. Direito ao ambiente e propriedade privada: aproximação ao estudo da estrutura e das conseqüências das "leis-reserva" portadoras de vínculos ambientais. Coimbra: Coimbra, 2001. p. 22

${ }^{60}$ MIRANDA, Jorge. Manual de direito constitucional: direitos fundamentais. 2. ed. Coimbra: Coimbra, 1998. t. 4. p. 471-472.

${ }^{61}$ Ibid., p. 473

${ }^{62}$ MIRANDA, Jorge. Manual de direito constitucional: direitos fundamentais. 2. ed. Coimbra: Coimbra, 1998. t. 4. p. 475. E nessa perspectiva, faz uma importante observação: “é duvidoso que possa falar-se num único, genérico e indiscriminado direito ao ambiente e, por certo, não existe um direito ao ordenamento do território. Porém, toda a matéria, directa ou indirectamente, vem a projetar-se no domínio dos direitos fundamentais não apenas por causa da sua inserção sistemática, mas sobretudo por a garantia, a promoção e a efetividade desses direitos se encontrarem no cerne do Estado de Direito democrático (art. $2^{\circ}$ e $9{ }^{\circ}$ alíneas c) e d) ).’Ibid., p. 475

${ }^{63}$ Ibid., p. 475

PRISMAS: Dir., Pol.Pub. e Mundial., Brasília, v.3, n, 2, p 288- 311, jul/dez.2006 

que, a partir da leitura do n. 1 do artigo 66 da constituição portuguesa, percebe-se uma natureza bidimensional do direito ao ambiente e que:

Não restam dúvidas acerca da opção constitucional de positivação do direito ao ambiente como direito análogo aos direitos, liberdades e garantias, do seu n. 2, não pode, seguramente, deixar de inferir-se a natureza social do mesmo, a julgar pelas incumbências, que neste domínio, o legislador constitucional determinou para o Estado, no exercício de qualquer uma das suas funções. Com a expressão da natureza "bidimensional" ou "bifronte" do direito ao meio ambiente não se pretende, no entanto, individualizar ou isolar duas categorias de direitos fundamentais autônomos. O que se quer demonstrar é exactamente o oposto: o direito ao meio ambiente é um direito fundamental uno, embora integrado, à semelhança das moedas, por duas faces diversas e necessariamente inseparáveis. ${ }^{64}$

Maria Fernandez salienta, entretanto, tratar-se de um direito fundamental que carece de preceptividade, quer dizer, depende a definição de sua medida e positivação jurídica de uma tarefa expansiva do legislador ordinário, para que se garanta efetividade ao sistema jurídico-constitucional de proteção ambiental.

Vasco Pereira da Silva também considera o direito ao ambiente como direito fundamental e busca desenvolver sua argumentação a partir de três perguntas ${ }^{65}$, ressaltando a dupla natureza do direito ao ambiente como direito subjectivo e como estrutura objectiva da coletividade. A esse respeito, ele destaca que:

[...] entendo que, sendo o Direito uma realidade humana, reguladora de relações entre as pessoas, não devem ser confundidos os domínios dos direitos individuais com os da tutela jurídica objectiva. Como sugestivamente escreve Henke, $<<_{0}$ direito que existe independentemente da minha pessoa [...] é, como é óbvio, algo diferente do meu direito, que eu tenho relativamente a outrem $>>$.

Ora, no Direito do Ambiente tanto existem direitos subjectivos das pessoas relativamente ao meio-ambiente, no quadro de relações que têm como sujeitos passivos entidades públicas e privadas, como a tutela objectiva de bens ambientais. ${ }^{66}$

${ }^{64}$ FERNANDEZ, Maria Elizabeth Moreira. Direito ao ambiente e propriedade privada: aproximação ao estudo da estrutura e das conseqüências das "leis-reserva" portadoras de vínculos ambientais. Coimbra: Coimbra, 2001. p. 26-27

65 "1) Saber se o direito ao ambiente é um direito fundamental ou uma tarefa estadual "disfarçada"; 2) Saber se o direito ao ambiente deve ou não ser considerado como um direito subjectivo; 3) Saber quais as conseqüências em termos de regime decorrentes da natureza jurídica do direito ao ambiente." SILVA, Vasco Pereira da. Verde cor de direito: lições de direito do ambiente. Coimbra: Almedina, 2002. p. 84 et seq.

${ }^{66}$ SILVA, Vasco Pereira da. Verde cor de direito: lições de direito do ambiente. Coimbra: Almedina, 2002. p. 26 
Contrária à idéia formulada por Vasco Pereira, Carla Gomes afirma que "existe uma insuficiência estrutural da fórmula do direito ao ambiente, que se traduz na impossibilidade de determinar o conteúdo de tal pretensão. ${ }^{, 67}$ E dessa forma, afirma que

[...] a protecção constitucional do ambiente se desdobra em duas facetas: objectiva - enquanto tarefa do Estado e demais entidades, públicas e privadas, num esforço de cooperação que vai desde a promoção e assimilação dos valores de educação ambiental à adopção de condutas que efectivamente traduzam uma atitude de preservação activa dos bens ambientais naturais; e subjectiva - enquanto dever de cada pessoa, física e jurídica, de proteger a qualidade dos bens ambientais, numa lógica solidária, intra e intergeracional. A impossibilidade de determinação da prestação que se verifica do lado activo não se reflecte no lado "passivo" (as aspas visam chamar a atenção para o facto de o dever não implicar necessariamente uma posição passiva, uma vez que se pode traduzir em comportamentos positivos, de facere), cabendo ao legislador definir, a propósito de cada situação, os deveres concretos que a cada pessoa incumbem no âmbito da responsabilidade repartida da proteç̧ão do ambiente. ${ }^{68}$

Vale ressaltar, por fim, a grande contribuição da doutrina portuguesa não só para a discussão da fundamentalidade do direito ao ambiente sadio e equilibrado, mas também para a própria idéia político-jurídica que subjaz a este direito, quer dizer: a idéia de um Estado ambiental $^{69}$.

\section{Conclusão}

Em vista de todo o exposto, parece claro que a complexidade de precisão da fundamentalidade do direito ao meio ambiente perpassa não só por sua recente percepção no direito (sobretudo constitucional) e contínua demarcação na discussão constitucional e jurisprudencial, mas também pela necessidade de maior enfrentamento de suas características

67 GOMES, Carla Amado. O direito ao ambiente no Brasil: um olhar português. Disponível em: $<$ http://www.esaf.fazenda.gov.br/parcerias/ue/cedoc-ue/monografia-2004/Artigo-Professora-Carla-AmadoGomes.pdf\#search=\%22um\%20olhar\%20portugues\%20\%22>. Acesso em: 24 ago. 2006. p. 09.

${ }^{68}$ Ibid., p. 16.

69 "Retomemos as considerações finais do número anterior. Dissemos que a pretensão de universalidade do Estado de direito se reconduz, no final do milênio, à formatação de um Estado dotado de qualidades: Estado de direito, Estado constitucional, Estado democrático, Estado social e Estado ambiental." CANOTILHO, José Joaquim Gomes. Estado de direito. Lisboa: Gradiva, 1999. p. 23. (Cadernos Democráticos, v. 7). 
e sistematização, em face, por exemplo, da dogmática de direitos fundamentais ${ }^{70}$. Nesse sentido, Alexy já nos adverte da relevância de maior clareza conceitual, no aprofundamento de uma dimensão analítica da dogmática ${ }^{71}$, para se buscar maiores ganhos objetivos na análise de direitos fundamentais e direitos ou valores correlatos.

Parece demonstrada, ainda, a confusão, a carência e a dificuldade de se delimitar a fundamentalidade de tal direito, que deve ser enfrentada com maior afinco, não apenas como um mister classificatório, mas, primordialmente, para um maior esclarecimento no lidar com as tensões constitucionais, que estão sempre às voltas de um direito ao meio ambiente ecologicamente equilibrado e que tendem a se acentuar cada vez mais, a partir daquilo que se convencionou chamar de sociedade de risco ${ }^{72}$. A partir do caso jurisprudencial proposto, a discussão demonstrou que esta tarefa está aberta e pendente de novas formulações. E a contribuição do Direito Comparado, aqui mencionado, demonstra que há vários caminhos ${ }^{73}$.

${ }^{70}$ Um exemplo da necessidade de maior enfrentamento da questão é ressaltado por Cristina Queiroz, em sua obra acerca dos direitos fundamentais, ao destacar que "de todo modo, é esse desenvolvimento e aperfeiçoamento constitucionais que postula a abertura a "novos" direitos fundamentais. No texto foi dada maior relevância aos chamados direitos de "autonomia", "privacidade", "intimidade" e "personalidade", mas trata-se de uma opção que não exclui outros direitos e pretensões que possam surgir "no decurso do tempo" e, designadamente, os chamados direitos de "terceira geração", principalmente os direitos ao "desenvolvimento", "meio ambiente" e "qualidade de vida"." QUEIROZ, Cristina M. M. Direitos fundamentais: teoria geral. Coimbra: Coimbra, 2002. p. 09.

${ }^{71}$ Resumidamente, ele destaca que a dimensão analítica da dogmática jurídica se preocupa com a consideração sistemático-conceitual do direito válido, estendendo suas tarefas de análise sobre diversos aspectos, tais como: análise de conceitos fundamentais, investigação da estrutura do sistema jurídico e sobre a fundamentação de base dos direitos fundamentais. Nesse sentido, consultar: ALEXY, Robert. Teoria de los derechos fundamentales. Trad. Ernesto Garzón Valdés. Madrid: Centro de Estudios Constitucionales, 1993. p. 30 et seq.

72 "In the last ten years the theory of risk society has been widely debated amongst sociologists. In his seminal book of this name, first published in Germany in 1986, Ulrich Beck argued that Western societies were moving into a new phase of modernity or modern life. The new phase is characterized by the pervasiveness of risk: of uncertainties, insecurities and hazards. [...] Life in contemporary societies has become more open-ended, less certain: there are more Jpossibilities, but also more risks. [...]. The risk society thesis thus places the environment at the hearth of contemporary politics. It makes the social control of science and technology into central political projects." JACOBS, Michael. Introduction: The new politics of the environment. In: JACOBS, Michael (Editor). Greening the Millennium: the new politics of the Environment. Oxford: Blackwell, 1997. p. 06-08.

${ }^{73}$ Cristina Queiroz ressalta os inúmeros desafios sobre o estudo dos direitos fundamentais e, com interesse ao proposto neste artigo, também como contribuição na busca da nota de fundamentalidade do direito ao meio ambiente ecologicamente equilibrado: "Devem os indivíduos ser protegidos unicamente do Estado (: "walls against the State") ou também pelo Estado? São os direitos bens públicos (: valores constitucionais)? Se o são, então, todos os direitos são direitos positivos. Implica o exercício desses direitos a correspondente responsabilidade? Geram os direitos sociais necessariamente dependência da esfera estadual? $\mathrm{O}$ reconhecimento de ("novos") direitos terá ido hoje longe de mais? Que relação existe entre o reconhecimento de direitos e expectativas de integração e uma política conseqüente de inclusão social? Constitui a "integração" uma das funções essenciais ao Estado? Se assim é, terão os direitos um carácter inevitavelmente redistributivo? Este acervo de questões e interrogações constitui hoje o elenco de "idéias força" ou "conceito chave" da cultura européia ocidental no que concerne à temática dos direitos e liberdades fundamentais: o conjunto das condições jurídico-positivas da respectiva institucionalização, e posterior constitucionalização, sem esquecer os relevantes aspectos de tensão e os desafios que se colocam no limiar do século XXI.” QUEIROZ, Cristina M. M. Direitos fundamentais: teoria geral. Coimbra: Coimbra, 2002. p. 10 
Contudo, a fundamentalidade material do direito ao meio ambiente ecologicamente equilibrado, ainda que não configurada claramente, não diminui a sua relevância, pois permanece a relevância essencial do bem que se protege e que, ao menos em termos de fundamentalidade formal, parece estar bem assegurado.

Em verdade, o que se entende a partir dessa discussão é que tanto a fundamentalidade formal, quanto a fundamentalidade material, são dimensões conectadas de uma só fundamentalidade e, cada qual, exerce um papel imprescindível. Conformar essas dimensões à realidade concreta é que parece ser o grande desafio, independentemente da topografia constitucional em que determinado direito se encontra inserido.

Afinal de contas, caso o disposto no artigo 225 de nossa constituição federal estivesse sediado no artigo $5^{\circ}$ de nossa constituição, será que não teríamos que efetuar o mesmo caminho aqui proposto, qual seja, identificar continuamente, caso a caso, a fundamentalidade material e formal do direito que se protege? Ou seria, de forma fácil e imediata, tal direito proclamado por todos como um direito fundamental? Caso hoje fosse promulgada nossa constituição, não estaria ele certamente no artigo $5^{\circ}$ ? Parece que a primeira opção se mostra mais coerente, inclusive pelo fato de que, como ressaltou Cristina Queiroz, ao surgimento de novos direitos, esse "filtro" da investigação de sua fundamentalidade far-se-á sempre necessário.

Não por menos que tal consideração nos direciona a uma segunda consideração, em conseqüência daquela. Exatamente porque essa investigação é necessária, caso a caso, que se ressalta a importância da necessidade de análise de casos concretos, quer dizer, não se pode afirmar a fundamentalidade de um direito em termos gerais e abstratos, mas somente e sempre pela guia das peculiaridades do caso concreto, em que se delimita a parcela da realidade que o integra. E esta discussão nada mais faz do que evidenciar um confronto de idéias entre absolutistas e relativistas, em acreditarem, cada qual, respectivamente, em direitos fundamentais afirmados e garantidos desde já, e em direitos fundamentais afirmados a partir de casos concretos.

Dessa forma, ainda que o critério funcional de classificação dos direitos fundamentais não reconheça, de imediato, um lugar de fácil acomodação do direito em análise, contribui para a demonstração de que sua sede deve ser reconhecida e desenvolvida com a maior clareza possível, seja como direito fundamental ou não. A discussão da classificação do direito em análise como direito social ou não, como direito bidimensional ou bifronte (conforme a contribuição portuguesa) ou somente como bem ou valor constitucionalmente relevante deve se aprofundar, a fim de contribuir para uma solução 
constitucionalmente mais clara e adequada de resolução de tensões (colisões) constitucionais em que esteja envolvido.

E esta discussão sobre a classificação nos direciona a outras considerações. A primeira consiste na pergunta do por que classificar, quer dizer, qual a relevância disto: estaríamos a discutir o "sexo dos anjos" enquanto a vida flui incessantemente à nossa volta? Parece que não, se consideramos que qualquer classificação pode desempenhar um papel essencial, qual seja: compartilhar uma dimensão semântica dos signos lingüísticos (por meio de uma uniformização da linguagem) e assumir determinada orientação (opção) teórica do que se investiga.

A par dessa discussão, parece essencial buscar o desenvolvimento de mecanismos que assegurem o bem jurídico ambiental, constitucionalmente assegurado, e que dispõe hoje para sua proteção de algumas ações relevantes como, por exemplo, a ação civil pública e a ação popular - enquanto mecanismos constitucionalmente garantidores da proteção ao meio ambiente sadio.

Diante das permanentes e contínuas possibilidades de tensão do direito ao meio ambiente com outros valores constitucionais e direitos fundamentais, o aprimoramento de métodos de solução de colisão de tais direitos e valores deve ser desenvolvido, quer seja pela ponderação de bens constitucionais (como visto na ADI 3.540-MC/DF), quer seja por outra perspectiva metodológica. O importante, nesse caminho, é, também, a busca de métodos constitucionalmente adequados à resolução das tensões constitucionais que surgem da aplicação da constituição federal brasileira, que não aniquilem direitos, bens e valores constitucionalmente assegurados.

Artigo recebido em agosto de 2006

Aceito em outubro de 2006

\section{Referências}

ALEXY, Robert. Teoria de los derechos fundamentales. Trad. Ernesto Garzón Valdés. Madrid: Centro de Estudios Constitucionales, 1993.

ANTUNES, Paulo de Bessa. Direito ambiental. 7 ed. rev., ampl. e atual. Rio de Janeiro: Lúmen Júris, 2004. 
BARROSO, Luis Roberto. A proteção do meio ambiente na Constituição brasileira. Revista Forense, Rio de Janeiro, v. 317, p. 163, jan./mar. 1992.

BRASIL. Constituição (1998). Constituição da República Federativa do Brasil: Texto constitucional promulgado em 5 de outubro de 1988, com as alterações adotadas pelas Emendas Constitucionais n ${ }^{\circ} 1 / 92$ a 46/2005 e pelas Emendas Constitucionais de Revisão $n^{\circ} 1$ a 6/94. Brasília: Senado Federal, Subsecretaria de Edições Técnicas, 2005.

BRASIL. Supremo Tribunal Federal. Medida Cautelar em Ação Direta de Inconstitucionalidade 3.540-1 - Distrito Federal (ADI 3.540 - MC/DF). Relator: Ministro Celso de Melo. Julgado em 01 de setembro de 2005. Diário de Justiça, Brasília, 03 fev. 2006. Disponível em:

$<$ http://www.stf.gov.br/jurisprudencia/IT/frame.asp?PROCESSO=3540\&CLASSE=ADI\%2D MC\&cod_classe $=555 \& O R I G E M=I T \& R E C U R S O=0 \& T I P \_J U L G A M E N T O=M \& E M E N T A$ $=2219>$. Acesso em: 24 ago. 2005.

CANOTILHO, José Joaquim Gomes. Direito constitucional e teoria da constituição. 4. ed. Coimbra: Almedina, 2001.

Estado de direito. Lisboa: Gradiva, 1999. p. 23. (Cadernos Democráticos, v. 7).

Protecção do ambiente e direito de propriedade: crítica de jurisprudência ambiental. Coimbra: Coimbra, 1995.

COSTA NETO, Nicolao Dino de Castro. Proteção jurídica do meio ambiente: I florestas. Belo Horizonte: Del Rey, 2003.

FERNANDEZ, Maria Elizabeth Moreira. Direito ao ambiente e propriedade privada: aproximação ao estudo da estrutura e das conseqüências das "leis-reserva" portadoras de vínculos ambientais. Coimbra: Coimbra, 2001.

FIORILLO, Celso Antônio Pacheco. Curso de direito ambiental brasileiro. 5 ed. ampl. São Paulo: Saraiva, 2004.

GOMES, Carla Amado. O direito ao ambiente no Brasil: um olhar português. Disponível em: <http://www.esaf.fazenda.gov.br/parcerias/ue/cedoc-ue/ monografia-2004/ArtigoProfessora-Carla-Amado-Gomes.pdf\#search=\% 22um\%20olhar\%20portugues $\% 20 \% 22>$. Acesso em: 24 ago. 2006.

JACOBS, Michael. Introduction: The new politics of the environment. In: JACOBS, Michael (Editor). Greening the Millennium: the new politics of the Environment. Oxford: Blackwell, 1997.

MENDES, Gilmar Ferreira. Direitos Fundamentais e controle de constitucionalidade: estudos de direito constitucional. 3 ed. rev. e ampl. São Paulo: Saraiva, 2004.

MENDES, Gilmar F.; COELHO, Inocêncio M.; BRANCO, Paulo G. G. Hermenêutica constitucional e direitos fundamentais. Brasília: Brasília Jurídica, 2000.

MILARÉ, Edis. Direito do ambiente: doutrina, jurisprudência, glossário. 4 ed. rev. atual. e ampl. São Paulo: Revista dos Tribunais, 2005. 
MIRANDA, Jorge. Manual de direito constitucional: direitos fundamentais. 2. ed. Coimbra: Coimbra, 1998. t. 4

PORTUGAL. Constituição da República Portuguesa (promulgação em 02.04.1976 e entrada em vigor em 25.04.1976). VII Revisão Constitucional [2005]. Disponível em:

$<$ http://www.parlamento.pt/const_leg/crp_port/>. Acesso em: 24 ago. 2005.

QUEIROZ, Cristina M. M. Direitos fundamentais: teoria geral. Coimbra: Coimbra, 2002.

SARLET, Ingo Wolfgang. A eficácia dos direitos fundamentais. 5. ed. rev. atual. e ampl. Porto Alegre: Livraria do Advogado, 2005.

SILVA, Christine Oliveira Peter da. Hermenêutica de direitos fundamentais: uma proposta constitucionalmente adequada. Brasília: Brasília Jurídica, 2005.

SILVA, Geraldo Eulálio do Nascimento. Direito ambiental internacional. 2. ed. rev. e atual. Rio de Janeiro: Thex, 2002.

SILVA, José Afonso da. Direito ambiental constitucional. 5. ed. São Paulo: Malheiros, 2004.

SILVA, Vasco Pereira da. Verde cor de direito: lições de direito do ambiente. Coimbra: Almedina, 2002.

SIRVINKAS, Luís Paulo. Manual de direito ambiental. 3 ed. rev. e atual. São Paulo: Saraiva, 2005. 


\section{Resumo}

Este artigo examina uma importante discussão jurídica sobre a conservação do meio ambiente, a partir do estudo de um caso julgado pelo Supremo Tribunal Federal - STF (ADI 3.540-MC/DF), no qual foi afirmado expressamente que o direito ao meio ambiente sadio e equilibrado é um direito fundamental. Além disso, é sabido que a constituição federal brasileira oferece expressa proteção ao meio ambiente. Este artigo buscará enfatizar $\mathrm{o}$ debate $\mathrm{e}$ as implicações da possibilidade de se considerar o direito ao meio ambiente sadio e equilibrado como um direito fundamental. Partindo do exame dos fundamentos da decisão do caso judicial abordado, alguns importantes apontamentos podem ser traçados: primeiramente, o fato de que o STF está alçando o direito ao meio ambiente sadio e equilibrado do nível de direitos humanos ao patamar de direito fundamental; em segundo lugar, o caso indica que método (procedimento de ponderação) foi considerado mais eficiente à proteção deste direito; em terceiro lugar, o direito ao meio ambiente sadio e equilibrado é analisado a partir da perspectiva multifuncional dos direitos fundamentais; em quarto lugar, é apresentada a contribuição da doutrina portuguesa sobre a questão. Por fim, são elaboradas algumas considerações acerca do assunto.

Palavras-chave: Direito ao Meio Ambiente Sadio e Equilibrado. Direitos Fundamentais. Constituição Federal do Brasil. Meio Ambiente. Direito Ambiental e Constitucional. Ponderação de Direitos.
This article provides a review of an important discussion in environmental protection from a legal approach, starting with the study of a case ruled by the Brazilian Federal Supreme Court (ADI 3.540-MC/DF), which has expressively stated that the right to a healthy and balanced environment is a fundamental right. Moreover, it is well known that Brazilian Constitution explicitly supports protection to the environment. This article will focus on the debate and the implications of the possibility to regard the right to a healthy and balanced environment as a fundamental right. By analyzing the court rulings described below, some important conclusions may be drawn: first, the Supreme Court is lifting the right to a healthy and balanced environment from the level of human rights to that of fundamental right; second, the case indicates which method (balancing procedure) was considered most effective to protect those rights; third, the right to a healthy and balanced environment is analyzed from the multifunctional viewpoint of the fundamental rights. At last, the article presents the contribution of the Portuguese doctrine on the issue and proposes a few notes related to it.

Key words: Right to a Healthy and Balanced Environment. Fundamental Rights. Brazilian Constitution. Environment. Environmental and Constitutional Law. Balancing of Rights. 